\title{
THE PROPERTY IN ISLAM \\ (IMAM MUHAMMAD ABU ZAHRAH'S PERSPECTIVE)
}

\author{
Muhammad Badrun \& Mustaffa Abdullah \\ Department of Qur'an Study and Tafsir, Faculty of Ushuluddin, University of \\ Darussalam Gontor \\ Email: badr_syahir@yahoo.com
}

\begin{abstract}
Abstrak. Kepemilikan Dalam Islam (Perspektif Imam Muhammad Abu Zahrah). Berdasarkan pengamatan dari berbagai komunitas, jelas bahwa kebanyakan orang sangat ceroboh berkaitan dengan kepemilikan, bahkan hanya untuk mendapatkan keuntungan darinya, mereka sudah terbiasa untuk tidak memikirkannya, bahkan lebih memilih untuk mengabaikan hak milik untuk menghabiskan harta benda. Dalam pikiran mereka apa pun akan dilakukan, asal dapat memperolehnya walaupun mengesampingkan dari etika dan moral dalam cara mencapai dan meraihnya, mereka bebas untuk melakukannya. Ini adalah konsep properti yang sangat liberal. Sebagai cara hidup, Islam telah mengatur semua aspek kehidupan termasuk kepemilikan. Ada banyak ayat Al Qur'an serta ajaran Nabi Muhammad SAW tentang harta benda. Imam Muhammad Abu Zahrah, sarjana muslim Mesir yang terkenal dan terkemuka di awal abad dua puluhan adalah orang yang sangat tertarik dengan isu ekonomi yang memiliki niat dan keinginan yang besar dalam menerapkan hukum Islam, terutama mengenai isu riba (riba). Dia telah menulis beberapa artikel, makalah dan buku juga, tentang masalah riba. Selain itu, dia juga telah menulis satu set Alquran Interpretasi (Tafsir) di mana dia mengomentari beberapa ayat mengenai harta dan kekayaan.
\end{abstract}

Kata Kunci: Kepemilikan, Ketentuan, Infaq, Sadaqah.

Abstract. The Property in Islam (Imam Muhammad Abu Zahrah's Perspective). Based on an observation through many communities, it is obviously that people are very careless on the possession of property, or even merely to get the advantage from it. They used not to think about, but prefer to neglect, the rightness of owning, the rightness of acquiring and the rightness of spending the property. In their mind is whatever they can gain, irrespective to the ethic and moral on the way of reaching and gaining, is totally belong to them, and they are free to do so ever. It is a very liberal concept of property. As a way of life, Islamic order ruled all aspects of life including the ownership of the property. There many verses of Al Qur'an as well as the teaching of the prophet Muhammad PBUH about the property. Imam Muhammad Abu Zahrah, the famous and prominent Egyptian muslim scholar in the first twentieth century who has great intention and desire of the implementation of Islamic law was one who has keen interest on the issue of economy, especially on the issue of usury (riba). He has written several articles, papers and a book as well, on the subject of riba. Moreover, he has also written a set of Qur'anic Interpretation in which he commented on some verses concerning the property and wealth

Keywords: Property, Provision, Infaq, Sadaqah. 


\section{Indtroduction}

At the beginning of our discussion it is better to said that the most visible phenomenon among the people is that many of them are very careless on the possession of property or even to get the advantage from any. They used not to think about, but prefer to neglect, the rightness of owning, the rightness of acquiring and the rightness of spending the property as well. In their mind is whatever they can reach to and gain, irrespective to the ethic and moral on the way of reaching and gaining, is totally belong to them, and they are free to do so ever. It is a very liberal concept of property.

Moreover, the economic life system or the materialistic life paradigm is seems to be secularist more than Islamic, or at least, moralistic or philosophically based on. In addition to this reality and fact, the difficulty of survival in the daily life made some people supposed that there is no more system of economy or system of property owning than what is happening and done by majority of them. So they are very careless of the inviolability of the property.

Above all, because of that reality and fact, and some misunderstanding of religion concept there are some scholars of Islam among muslim scholars who try to interpret the Qur'anic text (verses) merely depend on the case and fact. Or better to say, to justify the reality of life with the verses of Qur'an. But not to pick the Qur'anic teaching up to the life, or to build up the life depend on the doctrine of Qur'an, as it is ought to ${ }^{1}$. They forget that religion, instead of saying the Qur'an and the Sunnah, is the last of four sources of knowledge and truthfulness or guidance as well that must be the last judge of any case and problem of life. Many of economic thoughts, at least in the concept of property ownership are not referred to the religious teaching, and merely based on human thought and the theories as well.

In general sense, property is physical or intangible entity that is owned by a person or jointly by a group of persons. And many people understand that depending on the nature of the property, an owner of property has the right to consume, sell, rent, mortgage, transfer, exchange or destroy his or her property, and or to exclude others from doing these things ${ }^{2}$. There is no more in their mind than a belief that the right to own property is a part of human nature and that is related to the instinct for 
Muhammad Badrun, Mustaffa Abdullah: The Property in...

survival and self preservation. Even though the nature has undergone the changes, but, anyhow the nature of property rights depends greatly on the kind of philosophy or ideology. And it seems that philosophically among people concern to the theory or attitude that physical well-being or material success and worldly possessions or progress constitute the greatest good and highest value in life ${ }^{3}$. Consequently, people are directed by the thought and attitude as well of gaining the wealth and collecting the property as many as they can, and usually neglecting the code of ethic and moral.

Many people do not concern to the way how they acquire and collect the property. Many people are careless of spending their belonging and wealth. And many of them do not aware of the rights of property and the claims on it as well. They only understand that the owner of property is free to consume, sell, rent, mortgage, transfer, exchange or destroy his or her property, and or to exclude others from doing these things. They think that Islam has not a concept of property ownership or the doctrine of materialistic life, and only teach its people the ritual worship.

So far, it is perhaps beyond their knowledge that ten centuries (one thousand years) before the most well known economist, Adam Smith (1723-1790), proclaimed his economic theory, there were many muslim scholars who has written (though not in specific book) about economics from an Islamic point of view. Moreover, three centuries before Smith's life Ibnu Khaldun (1332-1406 M/732-808 H) -the well known of earlier muslim sociologist- has offered his idea and thought on the economic theory through his well known book, al Muqaddimah or Prolegomena. Yes, this monumental work was written in the frame of history and sociology study, but there was fundamental point of view on economic aspect. The chief concern of this monumental work was to identify psychological, economic, environmental and social facts that contribute to the advancement of human civilization and the currents of history ${ }^{4}$.

Shortly, the economic issues i.e. the property ownership, the interest of bank, the usury (riba) etc. are not excluding the Islamic teaching and not beyond the muslim scholars concern as well. Imam Muhammad Abu Zahrah, the famous and prominent Egyptian ulama in the first twentieth century who has great intention and desire of the implementation of shariah was one the ulamas who has keen interest on the issue of economy, especially on the issue of usury (riba) ${ }^{5}$. He has written several 
articles, papers and a book as well, on the subject of riba. Moreover, he has also written a set of Qur'anic Interpretation (Tafsiir) in which he commented on some verses concerning the property and wealth. And for this precious opportunity, the writer wishes to know his thought and conception on the property (al mal) as cited and written in his Qur'anic Interpretation named "Zahratu al Tafasir".

\section{Imam Muhammad Abu Zahrah in Brief}

It is to know that Abu Zahrah, who has a complete name; Muhammad bin Ahmad bin Mustafa bin Ahmad bin Abdullah was one among prominent ulama in the first twentieth century. He was known as the brave and fundamental scholar who has great attention to the factual problems and high spirit for struggling the truthfulness and condemning any kind of injustice. He was been known as the prominent ulama in the implementation of syari'ah. He has a clear and fluent word which makes easy to be understood and not implies any ambiguity. He has high ability on a dialogue and discussion with strong memory of the reasons and proof ${ }^{6}$. He used to express whatever comes into his mind frankly and bravely especially against the injustice and tyranny. He has written many articles, especially for the magazine of "Liwa' el Islam", papers for both regional and international conferences or seminars, and books. He wrote in several fields of Islamic studies, i.e. Islamic Jurisprudence, Ulumul Qur'an and Tafsir, Aqidah and Islamic Thought, Religious Studies (Comparative Religions), Knowledge of Da'wah and Social Economics studies.

Abu Zahrah was born in 29th March 1898/1316 at the city of Western Province which is called Mahalla al Kubra, and situated at the northern of Tanta7. His family was among the well known and esteemed families at Mahalla al Kubra. It was known as religious family and Islamic broad minded family as well. His grand father Sheikh Mustafa, due to his broadness of religious and general knowledge, and his steady position among the people of Mahalla against the tyranny, was known as the Master of Mahalla (Sheikh al Mahalla) ${ }^{8}$. Abu Zahrah was grew up in this highly regarded family.

He started his intellectual life and scholarly career at the elementary school named al kuttab ${ }^{9}$ from which he studied reading and writing. Then he continued his 
Muhammad Badrun, Mustaffa Abdullah: The Property in...

study at the high school from which he memorized Al Qur'an and studied several general knowledge, such as mathematic and geography.

In 1913, when he was 15 years old, Abu Zahrah continued his study at Al Ahmadi Academy in Tanta. After he has completed the program, in 1916, he was enrolled at Shariah Judicial School, for he has gained the first position in the admission test selection. He spent 9 years duration for completing the program in this school which was he got his doctorate degree (al shahadat al'alamiyah) in 1925. Due to his high dedication to the knowledge and his prefer of teaching activities he did the Diploma program at Darul Ulum. He completed the program in 1927. And in the same year -as he was appointed as teacher in provisional program of Darul Ulum- he started his teaching activities.

In January 1933 Abu Zahrah started his academic activities. He was appointed as lecturer in Faculty of Ushuluddin, at Al Azhar University. By that time he prepared several recommended books for his lecture, such as Tarikhu al Jadal (History of Polemics), Al Khitabah (Rhetoric) and Tarikhu Al Diyanat al Qadimah (History of Ancient Religions), and started writing any kind of book which is he concerned. There are at least 41 tittles of the precious book written by Abu Zahrah ${ }^{10}$. Among his monumental books is the book of Ulumul Qur'an (al Mu'jizat al Kubra; AlQur'an) and Qur'anic exegesis or Qur'anic interpretation named Zahratu al Tafasir.

It is better to know that Zahratu al Tafasir was compiled in the latest several years before the die of Abu Zahrah. That is why this Tafsir has not completed or covered the whole Al Qur'an yet. It is only up to verse no. 19 of surah an Naml (27) and consists of 10 volumes. The book was printed and distributed by Daar el Fikri el Araby.

This humble paper is trying to explore Sheikh Zahrah point of view on some issues concerning the property i.e. the understanding of property or the interpretation of al mal, the understanding of provision (rizq), the conception of blessing (barakah) and glimpse on the danger of usury (riba) in the acquisition of wealth and property. 


\section{The Property in Islam}

To discuss any matter of life from Islamic point of view one should refer to the basic Islamic sources of teaching and doctrine; AlQur'an and al Sunnah (the prophetic traditions), and to derive his thought and idea from both. Concerning to the discussion on the matter of property there are numerous categorical references in the AlQur'an (verses) talking about it which are mentioning that God is the sole owner of all things in the heavens and earth (QS $2: 107$, QS $2: 255$, QS $5: 120$, QS $48: 14)^{11}$ Anyhow, it is necessary to understand firstly the etymological concept of the word property (al Mal) in order to reach to the correct understanding of the property conceptually and practically.

The word mal or al mal of Arabic is translated into property or wealth in English language ${ }^{12}$, which is mean any physical or intangible entity that is owned by a person or jointly by a group of persons ${ }^{13}$. It is mentioned in Lisan al 'Arab dictionary that $a$ l mal is derived from mawala, and means whatever belong to you from among the things. Originally, Ibn Athir said, the word mal is only related to the possession of gold and silver, and then generalized to an achievement and ownership of the goods and assets ${ }^{14}$. It means that whatsoever owned by human being is considered as al mal. And the fuqaha' (Islamic jurists), of course, have their own definition on al mal. They said that al mal is whatsoever possible of the possession, the acquisition and the utilization as usual utilization ${ }^{15}$. But in this occasion we are not going to discuss the jurists' views and understanding, as well as their debates on this subject.

For the starting point, every muslim should understand that Al Qur'an has given an obvious teaching and principal concept that everything is owned by Allah (God), and that property in the absolute sense belongs to Him. Allah is the ultimate and unlimited owner of all that is on earth. Allah has said:

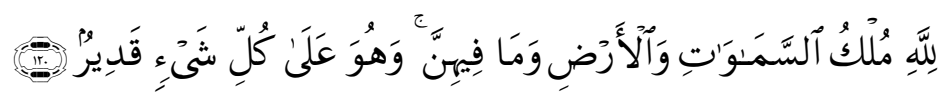

To Allah belongs the dominion of the heavens and the earth and All that is therein, and He is able to do all things ${ }^{16}$. 
Muhammad Badrun, Mustaffa Abdullah: The Property in...

The other verse indicates that actually human being is only the trustee of Allah on the earth. This makes man's ownership conditional, contractual and effectively fractionally. As long as he remains worthy of God's trust he has to enjoy the use and advantages of God's property ${ }^{17}$. Therefore his ownership of the property must be operated in the frame of this trust. Allah has said:

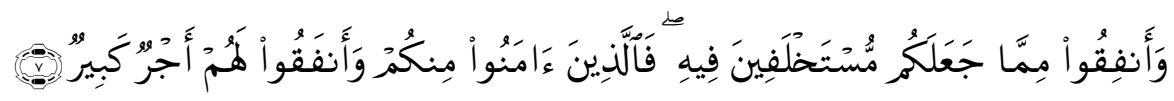

.... And spend of that whereof He has made you trustees. and such of you as believe and spend (in Allah's way), Theirs will be a great reward ${ }^{18}$.

And it is very obvious that the property and wealth belongs to the human being is actually bestowed by Allah, and all are owned by God and belong to Him alone. That is true, for mankind has no power and opportunity to work except from and because of the grace of Almighty Allah. Whatever done by human being in order to earn and collect the property and to survive in their life is no more than logical consequences of the life itself. But man cannot become an absolute owner, since ownership of all things, including man himself, belongs to God. Allah has said:

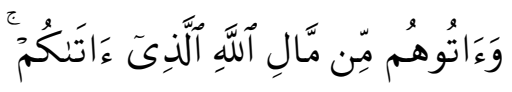

.... And give them something yourselves out of the wealth of Allah which He has bestowed upon you ${ }^{19}$.

However, it does not mean that, as human beings, then we do not have the right to own property. Not so. Anyhow, whatever provided by Almighty Allah is become our responsibility to consume it and to invest it as well, due to the rule of Allah. His Almighty has said:

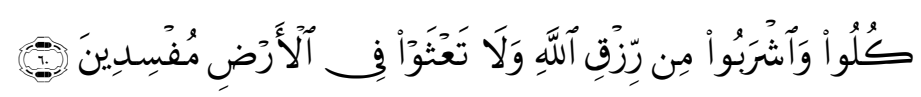

Eat and drink of that which Allah has provided and do not act corruptly, making mischief on the earth ${ }^{20}$. 
Islamiconomic: Jurnal Ekonomi Islam

Vol.8 No.1 Januari - Juni 2017

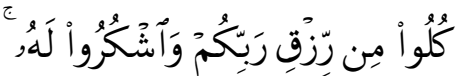

Eat of the provision of your Lord, and be grateful to him.....21
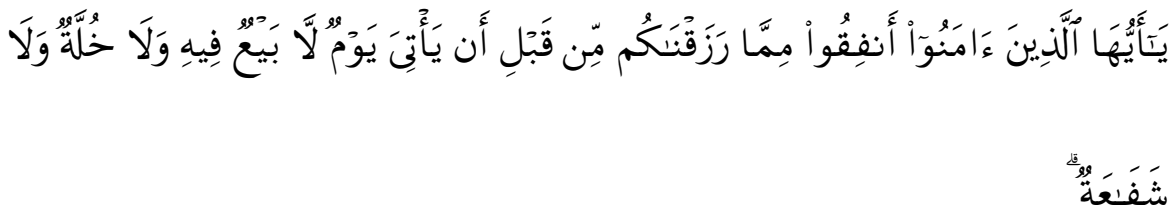

O You who believe! spend of that with which we have provided for you, before a day comes when there will be no bargaining, nor friendship, nor intercession ${ }^{22}$.

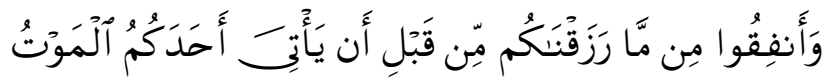

and spend (in charity) of that with which we have provided you, before death comes to one of you ${ }^{23}$.

In fact, there are many sayings of the prophet Muhammad saw, as well as his deeds (Hadith), concerning the wealth and property, i.e. the sayings related to the property transactions (al mu'amalat al maliyah) such as trade; buying and sale, loan, leasing etc. But, in the issue of the establishment of Islamic property philosophy just let's think deeply the following;

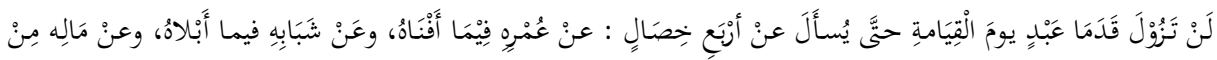

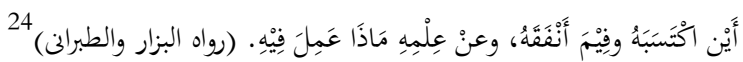

It will be nevermore terminated both of any creature's feet in the day after before questioned about four characteristics: about his age; how did he spend it, about his youth period; what did he spend it for, about his property; how did he acquire it and what did he expend it for, and about his knowledge; what did he work on it for.

Some muslims people have a misunderstanding on the concept of provision (rizq). They think that Allah will directly grant them this provision and provide it to 66 
Muhammad Badrun, Mustaffa Abdullah: The Property in...

them automatically, as He has said that no living creature is there on earth but its provision is due from Allah. "There is no moving creature on earth but its sustenance dependeth on Allah. He knoweth the time and place of its definite abode and its temporary deposit: all is In a clear record"25. So, they are lazy and don't want to work hard. Moreover, due to their misunderstanding on some verses and prophetic tradition texts about the trial of children and wealth, they do not want to struggle for seeking the enlarged provision by Allah. But, some of them have misconception on the ascetic life (zuhd). They think that this style of life means self embargo from the possession of property and wealth, or self withdrawal from the worldly life as well. No, it's not like that. The true zuhd is having the wealth in plenty without keeping it in minds but renounce it, and spend it in charity and for the sake of Almighty Allah ${ }^{26}$.

They forget that Allah has given them the complete equipments and tolls to undergo this life. Allah has subjected all that is on the earth to all mankind ${ }^{27}$, but subjected whatsoever is in the heavens and whatsoever is in the earth for the mankind ${ }^{28}$. Therefore the provision that has been stretched and increased by Allah to all mankind must be sought. And not be waited. Allah has said :

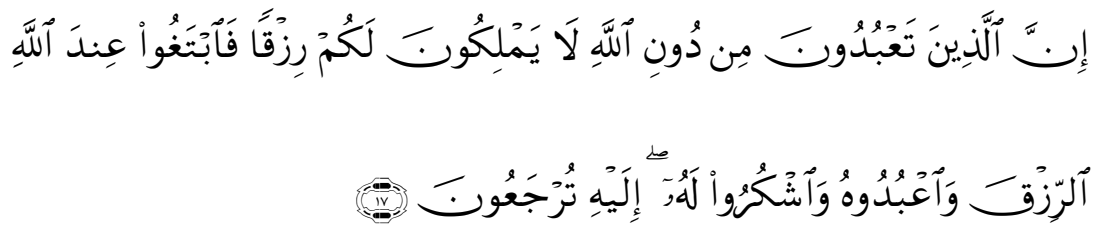

Verily, those whom you worship besides Allah have no power to give you provision, so seek your provision from Allah (Alone), and Worship Him (Alone), and be grateful to Him. To Him (Alone) you will be brought back $^{29}$.
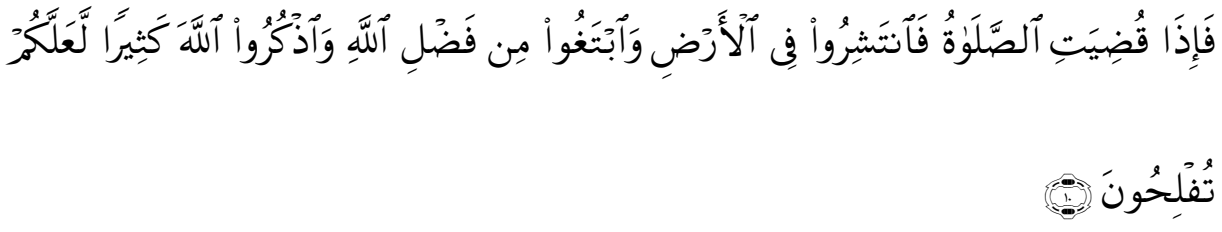
Islamiconomic: Jurnal Ekonomi Islam

Vol.8 No.1 Januari - Juni 2017

Then when the (Jum'ah) prayer is finished, you may disperse through the land, and seek the bounty of Allah (by working, etc.), and remember Allah much, that you may be successful ${ }^{30}$.

Almighty Allah has preferred some people above others in wealth and property, whether they are muslim or non-muslim. The preference of Allah provision is due to His grace and will as He gives wealth and sustenance to whom He will, and He doesn't give it to whom He will as well. "And it is He who has made you generations coming after generations, replacing each other on the earth. And He has raised you in ranks, some above others that He may try you in that which He has bestowed on you. Surely your Lord is Swift in retribution, and certainly He is Oft-Forgiving, Most Merciful". ${ }^{31}$

Therefore, in order to not misbehave upon the fact of differential and superiority of the provision, which is usually conducted improperly by many muslim people, Rasulullah Peace be upon him has reminded us that a man -in the sight of Allah- is measured not with his property and wealth. It has been narrated by Imam Ahmad that He said:

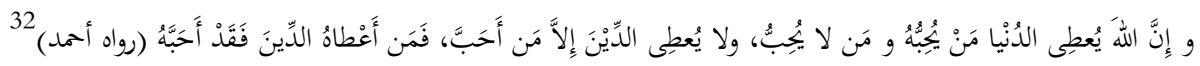

Verily, Allah will give him who He likes and dislike the world, and will not give the religion (din) only to whom He likes. So who has given the din meaning that Allah is, really, love him

Because the wealth and children are the adornment of the life of this world therefore the word "world" is used directly in this hadith. And it is very obvious in reality of life that Allah grant the provision to anyone whom He whish.

The principal idea that must be kept in the mind of all muslims is that everyone of them has to struggle in his life and to seek the provision of Allah, which is stretched around of the earth and heavens, through the right path and then, eventually, spend his belongings for the correct aim and in the right way. Shortly, the muslim must understand well the limit of property rights, the legitimates acquisition of property, the ethics of property rights and last but not least is the claim on the property. 
Muhammad Badrun, Mustaffa Abdullah: The Property in...

\section{Abu Zahrah's Perspective on Property.}

\section{The Understanding of Property (al Mal) and Provision (al Rizq)}

The word mal and all its derivative words are mentioned in the Holy Qur'an more than 80 times $^{33}$. It is indicating that the matter of material aspect (property) get the great attention in Islamic system of life. For Islam does not separate or differentiate between material life and the spiritual one. There is tight inter-relation in between.

The word mal or its derivation in the Qur'an is mentioned firstly at verse no. 155 of surah Al Baqarah (2). In which Allah Almighty reminding all mankind that He will test them with something of fear, hunger, lost of wealth, lives and fruits. But Abu Zahrah doesn't give any specific commentary and doesn't interpret the word al amwal which is mentioned in the verse specifically. Zahrah starts giving the commentary on the issue of property while explaining the meaning of the word rizq or its derivation (razaqnahum) in surah Al Baqarah. According to Abu Zahrah the word rizq means all kinds of the gift ( $\left.a l^{\prime} a t a\right)^{34}$ from Almighty Allah including animals, money, foods and residence which are giving the pleasure and enjoyment.

Abu Zahrah didn't agree with the view of some ulamas who say that the true provision of Allah is only the lawful (halal) one. According to him, Allah has given whatsoever needed by human being, and their selves who make the provision of Allah become lawful or unlawful one ${ }^{35}$. Then he mention verse no. 59 of surah Yunus :

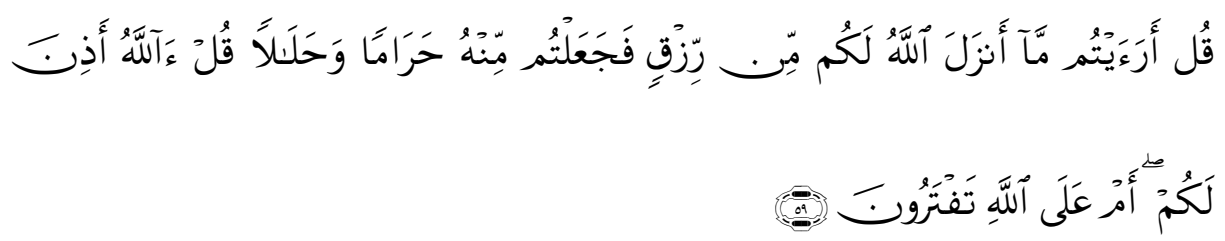

Say (O Muhammad to these polytheists): "Tell Me, what provision Allah has sent down to you! and you have made of it lawful and unlawful." Say (O Muhammad ): "Has Allah permitted you (to do so), or do You invent a lie against Allah?" 
Islamiconomic: Jurnal Ekonomi Islam

Vol.8 No.1 Januari - Juni 2017

Moreover he insists that human's belongings and property is not, in fact, the result of their pure effort but also from the given provision of Allah ${ }^{36}$. Allah is the only who provide or not provide the provision to whom He wish. Whatever you spend from your property is not from yourself but from the only Provider, Allah swt..

According to Abu Zahrah the basic principal of obtaining the property is respecting the others' ownership and passing the true path for it. Avoiding the unjustly ways of getting the wealth, such as stealing, robbing, deceiving etc. and preventing the unlawful method one. Allah says : "and eat up not one another's property unjustly (in any illegal way e.g. stealing, robbing, deceiving, etc.)....."

And about the using of word 'eat' instead of take or collect, Abu Zahrah explain that the fundamental motive of collecting property and obtaining the wealth is due to objective of having meal and eating 37 .

Shortly, Abu Zahrah believe that the possessive expression (amwalakum) used by the verses of collecting property indicates to the public purpose and public interest of the property ownership. Basically, all properties are belongs to public. It is provided to the individual ownership and personal property for the sake of people.

\section{The Understanding of Infaq}

The word infaq is derived from the word anfaqa which is mean to spend ${ }^{38}$, to expend, i.e. to spend the provision of Allah, to spend the property for the life. Everyone should have the awareness of spending his property properly and correctly. It will come into the existence if he belief that whatsoever belong to him is not purely from his own effort, but from the kindness of Allah; from the provision of Allah which is stretched for all human kind.

Infaq or nafaqah is also means the on spot gift or donation as a matter of charity. It's the realized donation obligated by the own necessity of who gives it or the necessity of the community he live in and the social necessities. ${ }^{39}$

To use the expression of al sadaqah (alms) instead of al infaq (spending the property) is to indicate that the complimented of declared spending of the property is the charities in which a pupil intend to reach the satisfaction of the Lord, with the prove intention and a pure heart. ${ }^{40}$ 
Muhammad Badrun, Mustaffa Abdullah: The Property in...

Interpreting the word infaq Sheikh Abu Zahrah remind us that to gain the rightness (al haqq) one should struggle and work hard. And spending the property for others or for public interest (al maslahah al 'ammah) in the sake of Allah is among heavy struggle and hard work. That's why Abu Zahrah reminds us about struggle and jihad. Moreover, the infaq verses in surah $\mathrm{Al}$ Baqarah is historically and philosophically relating to the property expenditure in the path of Allah done by Abdurrahman ibn 'Auf and Uthman ibn 'Affan r.a. during the war of Tabuk.

In order to get the promised reward from spending the property in the cause of Allah one has to do it in the pure soul (طيب النفس); without reminders his generosity, or mentioning it to others, without injury and without any intention of being to be seen by others. For who has expended his property in order to be seen by others is considered become a polytheist. Rasulullah saw said: "Anyone who offer praying due to be seen by others is considered to be a polytheist, anyone who fast in order to be seen is considered to be a polytheist and anyone who give charity in order to be seen is considered to be a polytheist". ${ }^{4}$

Furthermore, concerning to the acquisition of the property and its expenditure Sheik Abu Zahrah said: "In fact, Allah is the only who provide the property for them so they can spend it for others. He is the only who affect and stir their heart so they kind to give the others. And, He is, in fact, the only owner of them and whatsoever they spend and all of their deeds"42. So, the expression of (لهم أجرهم عند ربهم); their reward is with their Lord is indicating to the very kindness of Allah. Allah has granted the reward, and man should not worry about. Therefore they have to spend their property sincerely and only for the sake of Allah.

According to Abu Zahrah, spending the property in the way of Allah and for the sake of Allah is the only way out of property problematic. The guarantee of no fear and nor shall they grieve for who has spent their property properly implies that the well managed property will produce social security; give the happiness to the giver and the enjoyment to whom being given. Moreover, it will be no more way of securing the property of the have man and protecting it as well than spending it in the right 
Islamiconomic: Jurnal Ekonomi Islam

Vol.8 No.1 Januari - Juni 2017

way. So, to some extend the poor man can enjoy with that property, and the public interest get its right also ${ }^{43}$.

\section{The Conception of Barakah (Blessing)}

In addition to the understanding of property and the spending of it the expenditure) is better to also know and understand as well Abu Zahrah's conception of the barakah (blessing). The word barakah it self means al nama' wa al ziyadah ${ }^{44}$ (the growth and the increase). It means the unlimited and senseless divine benefaction of anything, with non sensible addition. ${ }^{45}$

The first time he offers his concept on barakah is during the explanation of the reward of those who spend their wealth (in Allah's cause) by day and night, in secret and in public. While explaining the first reward; فلهم أجرهم عند ربهم (they shall have their reward with their Lord), he said that it means the reward with the comfort place (paradise) at the day after and in the world as well which is indicated by the existence of barakah, and also with the merit of mutual assistance and synergism which is resulted by the charity and the spent of wealth in the cause of Allah.

\section{Conclusion}

Islam in its very essence is religion of justice and equality. That is mean that to understand it one should refer to its basic sources in order to get proper starting point of view upon all problems occurred.

The problem of poorness, the lack of property, or it is used to called the problem of social welfare, is the global problem faced by all nations and countries all aver the world. That is true because the matter of property is concern to everyone and every group of people. To solve this problem or at least to discuss on it needs the right understanding on the issues surrounding the property.

Many muslim people have a misunderstanding and misconception on the issue of property. Some are very pessimistic and only understand that the property is automatically provided by Allah. Some are very prejudice and only know that property is the trial of Allah, so they become apathetic. And some other are very 
Muhammad Badrun, Mustaffa Abdullah: The Property in...

careless. They just think how to acquire the property and how to collect it, irrespective -to some extent- to the ethical value and religious doctrine.

Sheikh Muhammad Abu Zahrah was among the prominent ulama (Islamic scholar) in the first twentieth century who gave the enlightenment on the concept and understanding on the matter of property. His book on riba (usury) is very monumental and precious book on the issue of property. Moreover, his Zahratu al Tafasir of Qur'anic exegesis gives the broad knowledge on the Islamic teaching from all its aspects, including the economic aspect of life, especially the understanding of the concept of property.

\section{References}

Abd El Razzaq, Abu Bakar, 1984, Abu Zahrah Imamu Asrihi; Hayatuh wa Atharuh al Ilmy, Cairo : Dar el I'tisam

Anis, Ibrahim, et al., 1972, Al Mu'jam al Wasit, vol. I, First Edition, Istanbul: Al Maktabah al Islamiyyah

Al Misri, Abdurrauf, 1948, Mu'jam Al Qur'an, Second Edition, Beirut, Libanon: Dar el Surur

Baalbaki, Rohi, 2002, Al Mawrid a Modern Arabic-English Dictionary, 16 ${ }^{\text {th }}$ edition, Beirut : Dar el Ilmi Lil Malayin

Babily, Mahmud Muhammad, 1982, Al Mal fi Al Islam, Beirut : Dar el Kitab al Lubnany wa Maktbatu al Madrasah

Ibn Mandzur, Lisan al 'Arab, vol. 11

Muhammad, Ahmad Abdul 'Al, 2008, Al Sheikh Muhammad Abu Zahrah wa Fikruhu al Tarbawy, First Edition, Cairo : Al Ilmu wal Iman Li al Nashri wa al Tawzi'

Muhammad Fuad Abdul Baqi, Al Mu'jam al Mufahras Li Alfadzi Al Qur'ani al Karim, Cairo : Dar el Hadith, 1988

Nomani, Farhad and Rahnema, Ali, 1995, Islamic Economic Systems, Kuala Lumpur : Business Information Press

Said, Muhammad Ra'fat, 2002, Al Mal; Milkiyatuhu, wa Istithmaruhu wa Infaquhu, First Edition, Cairo : Dar el Wafa

Syubair, Muhammad Usman, 2006, Fatawa al Shaikh Muhammad Abu Zahrah, First Edition , Damascus : Dar el Qalam 
Islamiconomic: Jurnal Ekonomi Islam

Vol.8 No.1 Januari - Juni 2017

Zahrah, Muhammad Imam Abu, 1974, Zahratu al Tafasir, Vol. I, Cairo : Dar el Fikri el Araby

1985/1405, Tahrim al Riba Tandzimun Iqtishadiyun, Second Edition, Jeddah : Al Dar Al Su'udiyah

http://www.ummah.net/history/scholars/KHALDUN.html, Ibnu Khaldun.

http://www.quran-radio.com/persones3.htm, Abu Zahrah Alimun Jariun Jahara bi alHaqq wa Naddada bi al Batil

http://www.islamonline.net/Arabic/history/1422/01/article20a.shtml, Abu Zahrah 'Alimun Yu'rafu Qadruhu

http://ar.jurispedia.org/index.php/, Al Shaikh Muhammad Abu Zahrah Imamu 'Asrihi

\section{Endnotes:}

\footnotetext{
${ }^{1}$ Imam Abu Zahrah (1985/1405), Tahrim al Riba Tandzimun Iqtishadiyun, Second Edition, (Al Dar Al Su'udiyah, Jeddah), p. 13

2 See, Property, http://en.wikipedia.org/wiki/Property

3 See the definition of materialism in some dictionaries. See also, Materialism - What Matters ?, http://www. allaboutphilosophy.org/materialism.htm and
} http://www.answers.com/topic/materialism

${ }^{4}$ Look at, Ibn Khaldun, http://www.ummah.net/history/scholars/KHALDUN.html

5 Abu Zahrah has written the specified book on riba entitled "Tahrim al Riba Tandzimun Iqtishadiyun" (The Interdiction of Usury; an Economic Order) and some articles on riba collected in "Buhuth fi al Riba" (The Researches on Usury).

${ }^{6}$ Abu Bakar Abdul Razzaq, Abu Zahrah Imamu Asrihi; Hayatuh wa Atharuh al Ilmy, (Cairo : Dar el I'tisam, 1984), p 13. Look, Abu Zahrah Alimun Jariun Jahara bi alHaqq wa Naddada bi alBatil, http://www.quran-radio.com/persones3.htm

${ }^{7}$ Muhammad Usman Syubair, Fatawa al Shaikh Muhammad Abu Zahrah, First Edition , (Damascus : Dar el Qalam, 2006), p 12. There is no fixed date of his birthday on the hijri calendar mentioned in some biography except what is mentioned in some websites; $6^{\text {th }}$ Dzulqa'dah 1315. (Look at, Abu Zahrah 'Alimun Yu'rafu Qadruhu,http://www.islamonline.net/Arabic/history/1422/01/article20a.shtml and Abu Zahrah Alimun Jariun Jahara bi alHaqq wa Naddada bi alBatil, http://www.quranradio.com/persones3.htm and $\mathrm{Al}$ Shaikh Muhammad Abu Zahrah Imamu 'Asrihi, http://ar.jurispedia.org/index.php/ )

${ }^{8}$ Ahmad Abdul 'Al Muhammad, Al Sheikh Muhammad Abu Zahrah wa Fikruhu al Tarbawy, First Edition, (Cairo : Al Ilmu wal Iman Li al Nashri wa al Tawzi', 2008), p. 20

${ }^{9}$ Kuttab is a very traditional private Islamic institution founded and leaded as well by a pious and prominent sheikh or ulama' widely spread almost at the whole of around Egypt.

10 This amount is for the published books, excluding some papers of the seminars and conferences and several articles in magazines or journals. Totally, it is about 80 books which were written by Imam Abu Zahrah. Look, Abu Bakar Abdul Razzaq, Op Cit, p. 13 and 77.

11 Farhad Nomani and Ali Rahnema, Islamic Economic Systems, (Kuala Lumpur : Business Information Press, 1995), p. 66

12 Dr. Rohi Baalbaki, Al Mawrid a Modern Arabic-English Dictionary, 16 ${ }^{\text {th }}$ edition, (Beirut : Dar el Ilmi Lil Malayin, 2002), p. 939

13 Look, http://en.wikipedia.org/wiki/Property 
Muhammad Badrun, Mustaffa Abdullah: The Property in...

14 Ibn Mandzur, Lisan al 'Arab, vol. 11, p. 636

${ }^{15}$ Muhammad Ra'fat Said, Al Mal; Milkiyatuhu, wa Istithmaruhu wa Infaquhu, First Edition, (Cairo : Dar el Wafa, 2002), p. 13

${ }_{16} \mathrm{QS}$. Al Maidah $5: 120$

${ }^{17}$ Farhad Nomani and Ali Rahnema, Op. Cit., p. 66

${ }^{18} \mathrm{QS}$. Al Hadid $57: 7$

${ }^{19} \mathrm{QS}$. Al Nur $24: 33$

${ }^{20} \mathrm{QS}$. Al Baqarah, $2: 60$

${ }^{21}$ QS Saba', $34: 15$

${ }^{22} \mathrm{QS}$ Al Baqarah, $2: 254$

${ }^{23}$ QS Al Munafiiqun, $63: 10$

${ }^{24}$ It is also narrated by al Tirmidzi but with some difference words. Look, Kanzul Ummal, hadith no. 9 and 11 and Majma'u al Zawaid, vol X, hadith no 346

${ }^{25}$ QS. Hud $11: 6$

${ }^{26}$ Mahmud Muhammad Babily, Al Mal fi Al Islam, (Beirut : Dar el Kitab al Lubnany wa Maktbatu al Madrasah, 1982), page 18

${ }^{27}$ Look, QS. Al Hajj, $22: 65$

${ }^{28}$ Look, QS Luqman, $31: 20$ and QS al Jathiyah, $45: 13$

${ }^{29} \mathrm{QS}$. Al 'Ankabut, $29 ; 17$

${ }^{30} \mathrm{QS}$. Al Jum'ah, $62: 10$

${ }^{31} \mathrm{QS}$. Al An'am, $6: 165$

${ }^{32}$ Look, Jam'ul Fawaid, Hadith no. 111

${ }^{33}$ Muhammad Fuad Abdul Baqi, Al Mu'jam al Mufahras Li Alfadzi Al Qur'ani al Karim, (Cairo : Dar el Hadith, 1988), p. 682-683.

${ }^{34}$ Al Sheikh Abu Zahrah, Zahratu al Tafasir, Vol. I, (Cairo : Dar el Fikri el Araby, 1974), p. 107

35 Ibid

${ }^{36}$ Ibid, p 108

${ }^{37}$ Sheikh Muhammad Abu Zahrah, Op Cit, Vol. II, p. 568-569.

${ }^{38}$ Rohi Baalbaki, Op Cit, p. 197

${ }^{39}$ Sheikh Muhammad Abu Zahrah, Op Cit, vol. II, p. 1012

${ }^{40}$ Ibid, p. 1019

${ }^{41}$ Narrated by Imam Muslim

${ }^{42}$ Sheikh Muhammad Abu Zahrah, Op. Cit, vol. II, p. 976

${ }^{43}$ Ibid, p. 1040

${ }^{44}$ Ibrahim Anis, et al., Al Mu'jam al Wasit, vol. I, (Istanbul : Al Maktabah al Islamiyyah, 1972), First Edition, p 52

${ }^{45}$ Abdurrauf al Misri, Mu'jam AlQur'an, (Beirut, Libanon : Dar el Surur, 1948), Second Edition, p. 107. It

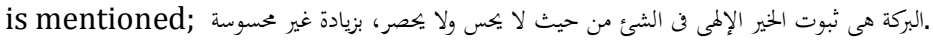


Islamiconomic: Jurnal Ekonomi Islam

Vol.8 No.1 Januari - Juni 2017 